\title{
ANALISIS KUALITAS PERAIRAN PADA EKOSISTEM MANGROVE BERDASARKAN KELIMPAHAN FITOPLANKTON DAN NITRAT FOSFAT DI DESA BEDONO DEMAK
}

\author{
Analysis of Aquatic Quality in Mangrove Ecosystem Based on Abundance of Phytoplankton and Nitrate Phosphate in \\ Bedono Village Demak
}

Ganjar Hesti Hutami, Max Rudolf Muskananfola*) dan Bambang Sulardiono

Program Studi Manajemen Sumberdaya Perairan

Departemen Sumberdaya Akuatik Fakultas Perikanan dan Ilmu Kelautan Universitas Diponegoro

Jl. Prof. Soedharto, SH Semarang

Email : ganjarhestihutami@gmail.com

\begin{abstract}
ABSTRAK
Perairan Bedono merupakan perairan bermangrove yang ada di Desa Bedono Kabupaten Demak. Kandungan nutrien yang ada di perairan ekosistem mangrove membuat ekosistem ini kaya akan unsur hara. Konsentrasi unsur hara sangat mempengaruhi kelimpahan biota yang ada di kawasan tersebut termasuk fitoplankton. Penelitian ini bertujuan untuk mengetahui kualitas perairan berdasarkan kelimpahan fitoplankton dan nitrat fosfat. Penelitian ini dilaksanakan pada bulan Januari-Februari 2017. Metode yang digunakan adalah metode deskriptif dengan teknik purposive sampling. Stasiun penelitian dibagi 3 stasiun dengan ulangan 3 kali. Pengambilan sampel fitoplankton menggunakan plankton net dengan mesh size $25 \mu \mathrm{m}$. Pengukuran parameter fisika kimia perairan dilakukan bersamaan dengan pengambilan sampel fitoplankton. Hasil analisis parameter fisika kimia air selama penelitian diperoleh temperatur air $\left(27-31^{\circ} \mathrm{C}\right)$, kecerahan $(7-44 \mathrm{~cm})$, kedalaman $(31-189 \mathrm{~cm})$, kecepatan arus $(0,03-0,4 \mathrm{~m} / \mathrm{s}) . \mathrm{pH} 7$, oksigen terlarut $(1,2-7,2 \mathrm{mg} / 1), \mathrm{CO}^{2}$ $(1,2-19,6 \mathrm{mg} / \mathrm{l})$, salinitas $(9-31)$, nitrat $(1,6-7,8 \mathrm{mg} / \mathrm{l})$, dan fosfat $(0,11-4,54 \mathrm{mg} / \mathrm{l})$. Fitoplankton yang teridentifikasi terdiri dari 18 genera. Kelimpahan fitoplankton tiap stasiun berkisar antara 1168-9045 ind/liter, keanekaragaman $(0,15-$ 2,08), keseragaman (0,07-0,99), dan dominasi (0,14-1,00). Hasil uji regresi linier menunjukkan bahwa konsentrasi nitrat lebih berpengaruh terhadap kelimpahan fitoplankton dengan nilai $\mathrm{t}$ hitung 2,743 dibandingkan dengan konsentrasi fosfat dengan $t_{\text {hitung }} 2,374$.
\end{abstract}

Kata Kunci : Kualitas Perairan; Kelimpahan Fitoplankton; Nitrat; Fosfat; Perairan Bedono

\section{ABSTRACT}

Bedono waters is one of the existing mangrove waters in the Demak Regency. The content of nutrients in the waters of mangrove ecosystems make this ecosystem rich in nutrients. Nutrient concentrations greatly affect the abundance of biota present in the region including phytoplankton. In addition to nutrients, water quality factors are also important to support the life of phytoplankton. This study aims to determine the quality of waters based on the abundance of phytoplankton and nitrate phosphate. This research was conducted in January-February 2017. The method used is descriptive method with purposive sampling technique. The research station is divided into 3 stations based on the tides, then each station is determined 3 point sampling. Sampling of phytoplankton using plankton net with mesh size 25 pm. Measurements of water chemistry physics parameters were performed simultaneously with phytoplankton sampling. The results of analysis of water chemistry physics parameters during the study obtained water temperature $\left(27-31^{\circ} \mathrm{C}\right)$, brightness $(7-44 \mathrm{~cm})$, depth $(31-189 \mathrm{~cm})$, current velocity $(0.03-0.4 \mathrm{~m} / \mathrm{s})$. PH 7, dissolved oxygen $(1.2-7.2$ mg / l), CO2 (1.2-19.6 mg / l), salinity (9-31), nitrate (1.6-7.8 mg / L), and phosphate (0.11-4.54 mg / l). The identified phytoplankton consists of 18 genera. The phytoplankton abundance of each station ranged from $1168-9045$ ind / liter, diversity (0.15-2.08), uniformity (0.07-0.99), and dominance (0.14-1.00). The result of linear regression test showed that nitrate concentration had more influence to phytoplankton abundance with 2,743 value compared to phosphate concentration 2,374.

Keywords: Water Quality; Abundance of Phytoplankton; Nitrate; Phosphate; The waters of Bedono

*) Penulis Penanggungjawab

1. PENDAHULUAN

${ }^{\circ}$ Copyright by Management of Aquatic Resources (MAQUARES) 
Wilayah perairan Bedono merupakan kawasan pesisir yang sebagian besar wilayahnya merupakan hutan mangrove. Adanya mangrove di sepanjang perairan Bedono sangat menunjang fungsi ekologi untuk daerah mencari makan, daerah pemijahan dan daerah pengasuhan. Ekosistem mangrove juga berperan penting untuk keberlangsungan ekosistem pesisir lainnya. Perputaran nutrient yang ada di perairan ekosistem mangrove di Desa Bedono menjadikan ekosistem ini kaya akan unsur hara. Ketersediaan unsur hara dipengaruhi oleh aktivitas masyarakat di sekitar area mangrove perairan Bedono, seperti kegiatan penangkapan ikan, limbah domestik dan juga kegiatan pertambakan.

Konsentrasi unsur hara berpengaruh terhadap kelimpahan biota termasuk fitoplankton. Fitoplankton dapat dijadikan bioindikator untuk mengetahui kondisi suatu perairan. Menurut Jannah dan Muchlisin (2012) salah satu organisme perairan yang sangat peka terhadap perubahan lingkungan adalah fitoplankton, oleh karena itu fitoplankton sering dijadikan bioindikator pencemaran dan kerusakan ekosistem perairan. Pada perairan yang tercemar biasanya ditandai dengan keragaman rendah dan adanya dominansi spesies tertentu.

Kelimpahan fitoplankton dapat dipengaruhi oleh unsur hara seperti nitrat dan fosfat. Nitrat merupakan zat hara utama yang dibutuhkan oleh fitoplankton untuk tumbuh dan berkembang dengan baik. Kandungan nitrat pada konsentrasi tertentu dapat memberikan kondisi tumbuh yang baik bagi fitoplankton dan dapat menjadi racun jika melebihi yang dibutuhkan.

Berdasarkan uraian di atas terdapat pengaruh yang ditimbulkan dari konsentrasi nitrat dan fosfat terhadap kelimpahan fitoplankton. Oleh karena itu dalam penelitian ini akan dikaji mengenai pengaruh konsentrasi nitrat fosfat terhadap kelimpahan fitoplankton di perairan ekosistem mangrove Desa Bedono.

Tujuan dari penelitian ini adalah :

1. Mengetahui konsentrasi nitrat dan fosfat di perairan Bedono Kabupaten Demak

2. Mengetahui kelimpahan fitoplankton di perairan Bedono Kabupaten Demak

3. Mengetahui hubungan nitrat dan fosfat terhadap kelimpahan fitoplankton

\section{MATERI DAN METODE PENELITIAN}

Materi yang digunakan dlam penelitian ini adalah sampel air yang diambil dari perairan ekosistem mangrove desa Bedono. Sampel air ini digunakan untuk menganalisa konsentrasi nitrat, fosfat dan kelimpahan fitoplankton. Variabel kualitas air yang dikur meliputi temperature air, kecerahan, kedalaman, kecepatan arus, salinitas, derajat keasaman (pH) dan oksigen terlarut. Alat yang digunakan adalah plankton net $25 \mu \mathrm{m}$ untuk menyaring fitoplankton, termometer air raksa untuk mengukur suhu, secchi disk untuk mengukur kecerahan, bola arus untuk mengukur kecepatan arus, refraktometer untuk mengukur salinitas, $\mathrm{pH}$ paper untuk mengukur $\mathrm{pH}$, botol Winkler untuk mengukur $\mathrm{DO}$ dan $\mathrm{CO}^{2}$, spektrofotometer untuk mengukur $\mathrm{N}$ dan $\mathrm{P}$.

Metode yang digunakan adalah metode deskriptif dengan teknik purposive sampling. Metode purposive sampling yaitu pengambilan sampel dengan tujuan tertentu dari peneliti yang diharapkan sampel dapat mewakili populasi dengan dasar pertimbangan daerah tersebut masih terkena pengaruh pasang surut. Sampling dilakukan pada bulan Januari-Februari 2017. Lokasi pengambilan sampel dibagi menjadi tiga stasiun yang terdiri dari : stasiun I berada di daerah bekas tambak, stasiun II berada di daerah mangrove dan stasiun III berada di area laut untuk jalur transportasi perahu nelayan, kemudian setiap stasiun ditentukan tiga titik sampling secara random. Pengambilan sampel dilakukan dengan tenggang waktu dua minggu.

Pengambilan sampel fitoplankton dilakukan dengan menggunakan metode sampling pasif pada setiap stasiun yang terdapat 3 titik sampling. Pengambilan sampel air untuk fitoplankton dengan cara menyaring 100 liter air ke dalam plankton net menggunakan ember dan gayung tangkai panjang. Hasil dari penyaringan tersebut didaptakan sampel fitoplankton sebanyak $50 \mathrm{ml}$. Setiap titik sampling didapatkan 1 botol sampel fitoplankton. Kemudian sampel fitoplankton dimasukkan ke dalam botol sampel dan dilakukan pengawetan menggunakan lugol 4\%. Jumlah sampel fitoplankton selama tiga kali pengulangan yaitu 54 botol sampel fitoplankton. Kelimpahan fitoplankton dihitung menggunakan Sedgwick-Rafter, sedangkan identifikasinya menggunakan buku identifikasi plankton Sachlan (1982) dan Yamaji (1986).

Perhitungan jumlah fitoplankton per liter, digunakan rumus APHA (1989), yaitu :

$$
\mathrm{N}=\frac{\mathrm{T}}{\mathrm{L}} \times \frac{\mathrm{P}}{\mathrm{p}} \times \frac{\mathrm{V}}{\mathrm{V}} \times \frac{1}{\mathrm{~W}}
$$

Keterangan :

$\mathrm{N}=$ Jumlah fitoplankton per liter

$\mathrm{T}=$ Luas gelas penutup $(\mathrm{mm} 2)$

$\mathrm{L}=$ Luas lapang pandang $(\mathrm{mm} 2)$

$\mathrm{P}=$ Jumlah fitoplankton yang tercacah

$\mathrm{p}=$ Jumlah lapang pandang yang diamati

$\mathrm{V}=$ Volume sampel fitoplankton yang tersaring $(\mathrm{ml})$ 
$\mathrm{v}=$ Volume sampel fitoplankton di bawah gelas penutup (ml)

$\mathrm{w}=$ Volume sampel fitoplankton yang disaring (liter

Perhitungan Indeks keanekaragaman (H') menurut Shannon dan Wiener (1949) dalam Odum (1993) dengan formula sebagai berikut :

$$
\mathrm{H}^{\prime}=-\sum_{\mathrm{i}=0}^{\mathrm{S}} \mathrm{Pi} \ln \mathrm{Pi}
$$

Keterangan :

$\mathrm{H}^{\prime}=$ Indeks Keanekaragaman

$\mathrm{P}_{\mathrm{i}}=$ Suatu fungsi peluang untuk masing-masing bagian secara keseluruhan

$\mathrm{n}_{\mathrm{i}}=$ Jumlah individu jenis ke-i

$\mathrm{N}$ = Jumlah individu total

Perhitungan Indeks keseragaman berdasarkan persamaan Odum (1993) adalah sebagai berikut:

$$
e=\frac{H^{\prime}}{\ln S}
$$

Keterangan:

$\mathrm{e}=$ indeks keseragaman

$\mathrm{H}^{\prime}=$ indeks keanekaragaman

$\mathrm{S}=$ jumlah jenis berikut :

Perhitungan Indeks Dominansi menggunakan Indeks Dominansi Simpson (Odum, 1993) dengan rumus sebagai

$$
\mathrm{C}=\Sigma\left(\mathrm{n}_{\mathrm{i}} / \mathbf{N}\right)^{2}
$$

Keterangan:

$\mathrm{C}=$ Indeks dominansi

$\mathrm{n}_{\mathrm{i}}=$ Jumlah individu jenis ke- $\mathrm{i}$

$\mathrm{N}=$ Jumlah total individu

Perhitungan Indeks Similaritas menggunakan Indeks Similaritas Sorensen dengan rumus sebagai berikut :

$$
\mathbf{S}=\mathbf{2 C} / \mathbf{A}+\mathbf{B}
$$

Keterangan:

$\mathrm{S}=$ Indeks similaritas,

$A=$ Jumlah spesies pada tempat A,

$\mathrm{B}=$ Jumlah spesies pada tempat $\mathrm{B}$,

$\mathrm{C}=$ Cacah spesies pada tempat $\mathrm{A}$ maupun $\mathrm{B}$.

Setelah mendapatkan hasil data primer melalui sampling lapangan dan analisa laboratorium, data akan diolah menggunakan uji regresi berganda. Analisis regresi berganda digunakan untuk mengetahui besarnya hubungan dan pengaruh variabel bebas (independen) X1 (konsentrasi nitrat) dan X2 (konsentrasi fosfat) terhadap variabel tak bebas (dependen) Y (kelimpahan fitoplankton). Perangkat lunak yang digunakan untuk analisa data ini adalah SPSS versi 16.

\section{HASIL DAN PEMBAHASAN}

Hasil

Kelimpahan Fitoplankton, Indeks Keanekaragaman, Indeks Keseragaman, Indeks Dominansi

Berdasarkan hasil identifikasi yang teah diakukan, fitoplankton yang terdapat di perairan Bedono terdiri dari 18 genera. Rata-rata kelimpahan fitoplankton di perairan Bedono berkisar antara 1.168-5.768 ind/1. Nilai indeks 
keanekaragaman saat pasang dan surut berkisar antara 1,22-1,87. Nilai indeks keseragaman saat pasang dan surut berkisar antara 0,53-0,93. Nilai indeks dominasi saat pasang dan surut berkisar antara 0,17-0,46. Hasil uji laboratorium terhadap konsentrasi nitrat di perairan Bedono menunjukkan nilai berkisar antara 2,29-4,8mg/L sedangkan konsentrasi fosfat menunjukkan nilai berkisar $0,17-0,41 \mathrm{mg} / \mathrm{L}$.

Nilai indeks keseragaman saat pasang dan surut berkisar antara 0,53-0,93. Nilai indeks dominasi saat pasang dan surut berkisar antara 0,17-0,46.

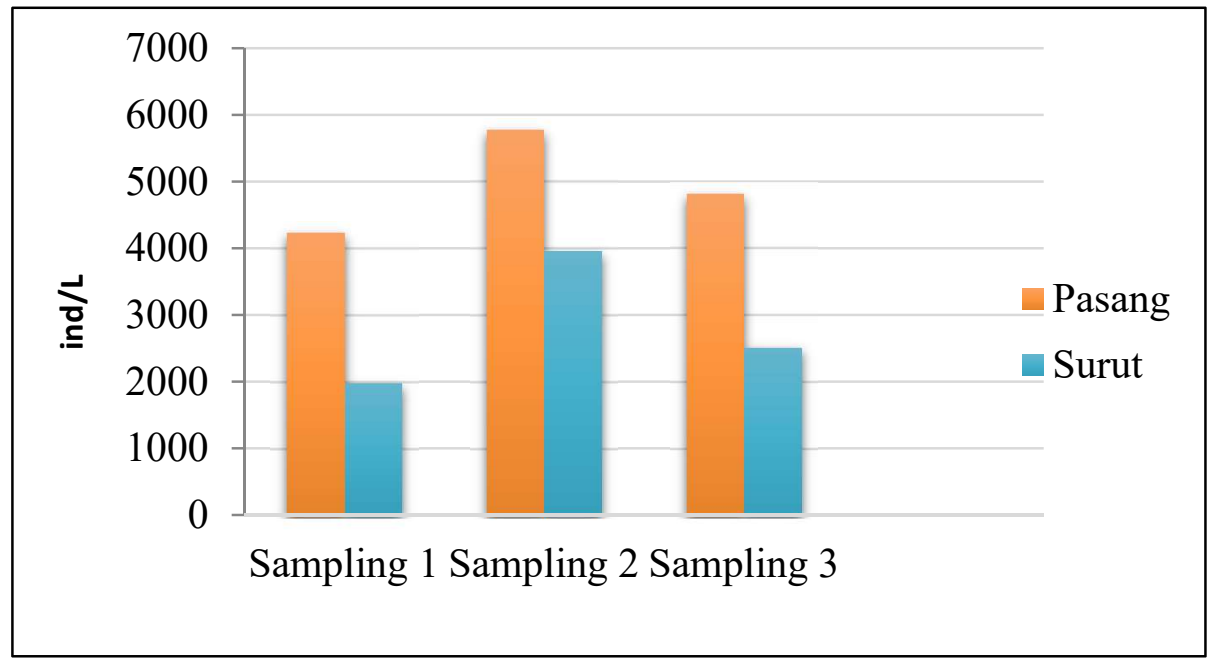

Gambar 1. Histogram Kelimpahan Fitoplankton (ind/1)

Hasil uji laboratorium terhadap konsentrasi nitrat di perairan Bedono menunjukkan nilai berkisar antara 2,294,8 mg/L. Distribusi nilai konsentrasi nitrat di lokasi penelitian dapat dilihat pada Gambar 2.

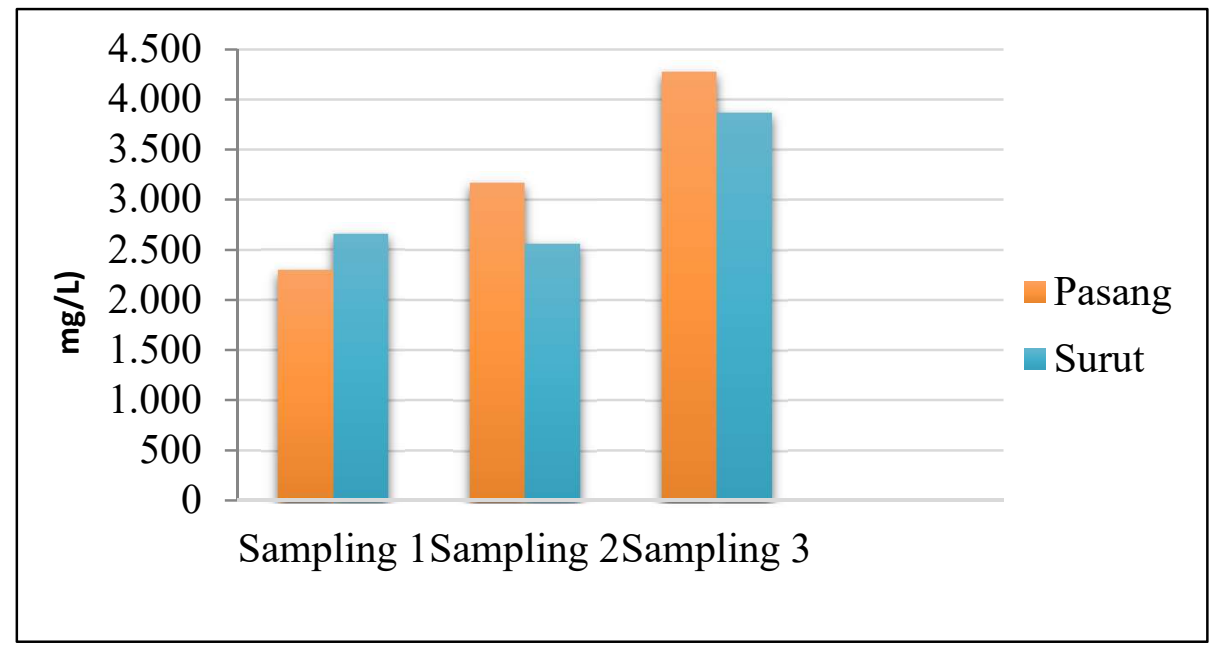

Gambar 2. Histogram Konsentrasi Nitrat (mg/L)

Hasil uji laboratorium terhadap konsentrasi fosfat di perairan Bedono menunjukkan nilai berkisar 0,17-0,41 $\mathrm{mg} / \mathrm{L}$. Distribusi nilai konsentrasi fosfat di lokasi penelitian dapat dilihat pada Gambar 3. 


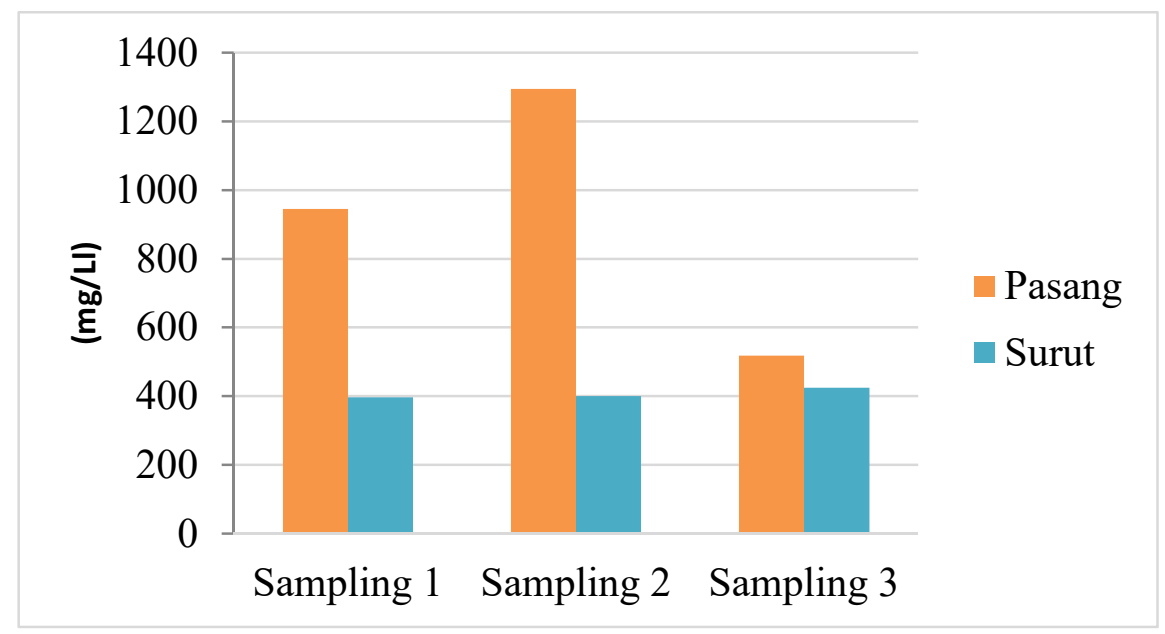

Gambar 3. Histogram Konsentrasi Fosfat (mg/L)

\section{Hubungan Nitrat dan Fosfat Terhadap Kelimpahan Fitoplankton}

Hasil analisa didapat melalui analisis regresi berganda dengan nilai koefisien korelasi (R) sebesar 0,867 yang berarti hubungan nitrat dan fosfat terhadap kelimpahan fitoplankton dikategorikan berhubungan kuat. Nilai koefisien determinasi (R2) sebesar 0,752 nilai ini menunjukkan sebesar 75,2\% kelimpahan fitoplankton dipengaruhi oleh konsentrasi nitrat dan fosfat, sisanya sebesar $24,8 \%$ dipengaruhi oleh faktor lain seperti faktor kimia fisika perairan Tabel 1. Kesimpulan Model Analisis Regresi Berganda

\begin{tabular}{lllll}
\hline Model & R & R Square & Adjusted R Square & Std. Error of the Estimate \\
\hline 1 & 0,867 & 0,752 & 0,669 & 720,69088 \\
\hline
\end{tabular}

Model regresi linier berganda diperoleh persamaan yaitu $\mathrm{Y}=-375+1491$ nitrat +510 fosfat. Hasil analisis pada tabel menunjukkan nitrat nilai $t_{\text {hitung }}$ sebesar 2,743 dengan probabilitas $=0,034<0,05$ artinya pada saat kondisi pasang nitrat berpengaruh signifikan terhadap kelimpahan fitoplankton. Selanjutnya fosfat nilai $t$ hitung sebesar 2,374 dengan probabilitas $=0,055>0,05$ artinya fosfat tidak memiliki pengaruh yang signifikan.

Tabel 2. Persamaan Regresi Linier Ganda

\begin{tabular}{|c|c|c|c|c|c|c|}
\hline & \multirow[b]{2}{*}{ Model } & \multicolumn{2}{|c|}{ Unstandardized Coefficients } & \multirow{2}{*}{$\begin{array}{c}\text { Standardized } \\
\text { Coefficients }\end{array}$} & \multirow[b]{2}{*}{$\mathrm{t}$} & \multirow[b]{2}{*}{ Sig. } \\
\hline & & $\mathrm{B}$ & Std. Error & & & \\
\hline \multirow[t]{3}{*}{1} & (Fitoplankton) & -375.065 & 1737.534 & & -.216 & .836 \\
\hline & Nitrat & 1491.477 & 543.741 & .581 & 2.743 & .034 \\
\hline & Fosfat & 510.114 & 214.908 & .502 & 2.374 & .055 \\
\hline
\end{tabular}

Sedangkan untuk kondisi surut, menunjukkan nilai koefisien korelasi (R) sebesar 0,328 yang berarti hubungan nitrat dan fosfat terhadap kelimpahan fitoplankton dikategorikan berhubungan lemah. Nilai koefisien determinasi (R2) sebesar 0,107 menunjukkan sebesar 10,7\% kelimpahan fitoplankton dipengaruhi oleh konsentrasi nitrat dan fosfat, sisanya sebesar $89,3 \%$ dipengaruhi oleh faktor lain.

Tabel 3. Kesimpulan Model Analisis Regresi Berganda

\begin{tabular}{ccccc}
\hline Model & R & R Square & Adjusted R Square & Std. Error of the Estimate \\
\hline 1 & 0,328 & 0,107 & $-0,190$ & 503,31778 \\
\hline
\end{tabular}

Model regresi linier berganda diperoleh persamaan yaitu $\mathrm{Y}=3642-346$ nitrat +548 fosfat. Hasil analisis pada tabel menunjukkan nitrat nilai t hitung sebesar -395 dengan probabilitas $=0,706>0,05$ artinya pada saat kondisi surut nitrat tidak berpengaruh signifikan terhadap kelimpahan fitoplankton. Selanjutnya untuk fosfat nilai $t$ hitung sebesar 559 dengan probabilitas $=0,596>0,05$ artinya fosfat tidak memiliki pengaruh yang signifikan terhadap kelimpahan fitoplankton.

Tabel 4. Persamaan Regresi Linier Ganda

\begin{tabular}{|c|c|c|c|c|c|}
\hline \multirow[b]{2}{*}{ Model } & \multicolumn{2}{|c|}{ Unstandardized Coefficients } & \multirow{2}{*}{$\begin{array}{c}\begin{array}{c}\text { Standardized } \\
\text { Coefficients }\end{array} \\
\text { Beta }\end{array}$} & \multirow[b]{2}{*}{$\mathrm{t}$} & \multirow[b]{2}{*}{ Sig. } \\
\hline & B & Std. Error & & & \\
\hline
\end{tabular}

${ }^{\circledR}$ Copyright by Management of Aquatic Resources (MAQUARES) 
Analisis Kualitas Perairan pada Ekosistem Mangrove berdasarkan Kelimpahan Fitoplankton dan Nitrat Fosfat

\begin{tabular}{ccccccc}
\hline 1 & (fitoplankton) & 3641.895 & 2828.416 & & 1,288 & 0,245 \\
& nitrat_surut & -346.538 & 876.249 & $-0,163$ & $-0,395$ & 0,706 \\
& fosfat_surut & 547.968 & 979.425 & 0,231 & 0,559 & 0,596 \\
\hline
\end{tabular}

\section{Parameter Fisika dan Kimia Perairan Bedono}

Hasil pengukuran parameter fisika kimia perairan Bedono selama penelitian yaitu, temperature air berkisar $27-32^{\circ} \mathrm{C}$, kecerahan berkisar 10-44 cm, kedalaman berkisar antara $26-189 \mathrm{~cm}$, kecepatan arus berkisar 0,03-0,33, salinitas antara 9-30, pH antara 6-7, konsentrasi nitrat 1,6-7,8 mg/L dan konsentrasi fosfat $0,1-4,8 \mathrm{mg} / \mathrm{L}$.

\section{Pembahasan}

\section{Kelimpahan Fitoplankton}

Hasil identifikasi fitoplankton dan perhitungan kelimpahan yang diperoleh dari sembilan titik sampling pada saat pasang dan surut di perairan Bedono Demak didapatkan 3 kelas yaitu Bacillariophyceae (13 genus), Cyanophyceae (2 genus) dan Dinophyceae (3 genus). Kelimpahan saat pasang cenderung lebih tinggi daripada ketika surut. Hal tersebut diduga karena unsur hara saat pasang lebih banyak. Zat hara tersebut bisa berasal dari aktivitas yang ada di sekitar perairan dan bekas tambak. Menurut Purwanti et al (2011) terjadinya pasang surut air laut sangat berpengaruh terhadap kemelimpahan fitoplankton di suatu perairan. Selain faktor pasang surut, berbagai aktivitas yang berlangsung di sepanjang perairan juga dapat mengakibatkan perubahan terhadap faktor fisika kimia perairan yang berdampak pada komunitas plankton. Pada saat pasang permukaan air akan bertambah tinggi yang mengakibatkan fitoplankton bertambah karena terbawa arus dan gelombang air laut.

Kelimpahan genus yang paling banyak ditemukan pada setiap titik baik saat pasang maupun surut yaitu dari kelas Bacillariophyceae. Menurut Sachlan (1982) Bacillariophyceae mempunyai sifat kosmopolit, tahan terhadap kondisi ekstrim, mudah beradaptasi dan mempunyai daya reproduksi yang sangat tinggi. Hal ini juga diperkuat oleh Basmi (1999) dalam Hidayat et al. (2013) bahwa diatom jenis Bacillariophyceae dan Dinophyceae merupakan jenis fitoplankton yang paling penting dan umum terdapat di laut.

Kelimpahan fitoplankton tertinggi yang didapatkan adalah Oscillatoria sp yang termasuk salah satu fitoplankton dari kelas Cyanophyceae. Hal tersebut sesuai dengan Pramitha (2010) dalam Kamilah et al. (2014), bahwa Oscillatoria sp yang merupakan anggota dari Cyanophyceae ditemukan paling dominan dalam kondisi tercemar ringan oleh bahan organik.

Nilai indeks keanekaragaman fitoplankton $\left(\mathrm{H}^{\prime}\right)$ saat pasang berkisar antara $1.22-1.87$. Sedangkan saat surut berkisar antara 1.44-1.81. Secara umum keanekaragaman fitoplankton di perairan Bedono termasuk stabil moderat. Hal ini juga sesuai dengan Wilhm (1975) dalam Rudiyanti (2009) yang menyatakan nilai keanekaragaman biota perairan dengan kisaran 1-2 mengindikasikan perairan dalam kualitas tercemar sedang dan nilai keanekaragaman dengan kisaran 1-3 mengindikasikan perairan dalam kualitas tercemar ringan. Nilai indeks keseragaman fitoplankton (e) saat pasang berkisar antara 0,53-0,93. Sedangkan nilai indeks keseragaman saat surut berkisar antara 0,81-0,93. Komunitas fitoplankton yang ada di perairan Bedono Demak ini tergolong hampir merata. Hal ini sesuai dengan Pielou (1977) dalam Faza (2012) bahwa nilai indeks keseragaman / kemerataan berkisar 0,00-0,25 tidak merata, 0,26-0,50 berarti kurang merata, 0,51-0,75 berarti cukup merata, 0,76-0,95 berarti hampir merata dan 0,96-1,00 merata. Menurut Odum (1993) dalam Pratiwi (2015) semakin kecil nilai E makan akan semakin kecil juga keseragaman suatu populasi yang artinya penyebaran jumlah individu tiap genus tidak sama dan ada kecenderungan bahwa suatu genera mendominasi populasi tersebut. Sebaliknya semakin besar nilai E maka populasi menunjukkan keseragaman yaitu jumlah individu setiap genus dapat dikatakan relatif sama.

Nilai indeks dominasi fitoplankton (C) saat pasang berkisar antara 0,17-0,53. Sedangkan nilai indeks dominasi saat surut berkisar antara 0,18-0,26. Hal tersebut berarti di lokasi penelitian tidak ada spesies fitoplankton yang mendominasi karena kisaran nilai mendekati 0. Menurut Aprianti et al., (2015) bahwa jika indeks dominasi (C) mendekati nilai 1, maka ada salah satu jenis yang mendominasi jenis lain. Nilai indeks dominasi plankton berkisar antara 0-1, bila indeks dominasi mendekati 0, berarti di dalam struktur komunitas biota yang diamati tidak terdapat jenis yang secara menyolok mendominasi jenis lainnya. Berdasarkan hasil perhitungan nilai indeks similaritas Sorensen, didapatkan hasil nilai indeks similaritas (kesamaan) antar stasiun diatas $92 \%$ mendekati 100\%. Hal tersebut mengindikasikan bahwa terdapat kesamaan komunitas antar titik sampling. Menurut Jannah dan Muchlisin (2012) indeks similaritas digunakan untuk melihat kemiripan komunitas fitoplankton antar stasiun yang nilainya antara 0100\%. Jika nilai mendekati $0 \%$ maka tingkat kemiripan rendah dan jika nilai mendekati $100 \%$ maka kesamaan komunitas antar stasiun tergolong tinggi dengan kata lain jika nilai indeks similaritas dibawah 50\% diartikan komunitas fitoplankton antar stasiun berbeda, sebaliknya jika indeks similaritas lebih dari 50\% maka terdapat kesamaan komunitas fitoplankton antar stasiun.

\section{Hubungan Kelimpahan Fitoplankton dengan Nitrat dan Fosfat}

Konsentrasi nitrat dan fosfat saat pasang dan surut di perairan Bedono memiliki nilai yang berbeda-beda. Konsentrasi nitrat berkisar antara 1,9-7,8 mg/l saat pasang dan 2,15-4,7 mg/l saat surut. Sedangkan konsentrasi fosfat 
berkisar antara 0,18-4,54 mg/L saat pasang dan 0,09-0,97 mg/L saat surut. Konsentrasi nitrat cenderung mengalami kenaikan pada setiap stasiun dan mengalami kenaikan yang signifikan pada stasiun 2 hingga mencapai 3,2 mg/l. Kenaikan konsentrasi nitrat juga diiringi dengan melimpahnya fitoplankton pada stasiun 2 dengan total 9065 ind/liter. Menurut Handoko et al., (2013) pola persebaran fitoplankton menunjukkan adanya keterkaitan dengan sebaran nitrat. Hal ini juga sesuai oleh Mackentum (1969) dalam Yuliana dan Tamrin (2007) bahwa untuk pertumbuhan optimal fitoplankton memerlukan kandungan nitrat pada kisaran 0,9-3,5 mg/l.

Data yang diolah menggunakan uji regresi linier berganda dengan selang kepercayaan $95 \%$ memberikan informasi bahwa konsentrasi nitrat dan fosfat berhubungan kuat dengan nilai 0,867 dengan koefisien determinasi sebesar 0,752. Hal ini berarti sebesar 75,2\% kelimpahan fitoplankton dipengaruhi oleh konsentrasi nitrat dan fosfat dan 24,8\% lainnya dipengaruhi oleh parameter fisika kimia di sekitar lingkungan perairan.

\section{Parameter Fisika Kimia di Perairan Bedono}

Suhu air berkisar antara $27-32^{\circ} \mathrm{C}$ baik saat pasang maupun surut. Menurut Effendi (2003) dalam Yuliana et al., (2012) bahwa kisaran suhu yang optimum untuk pertumbuhan fitoplankton di perairan adalah $20-30^{\circ} \mathrm{C}$.

Nilai kecerahan pada lokasi penelitian berkisar antara $7.5-38.5 \mathrm{~cm}$ pada saat pasang dan 7-36 cm pada saat surut. Nilai kecerahan dapat mempengaruhi kelimpahan fitoplankton karena fitoplankton membutuhkan cahaya dalam proses fotosintesis. Hal tersebut sesuai dengan pernyataan menurut Sulardiono et al. (2015) bahwa pertumbuhan algae sangat ditentukan oleh badan air. Air yang keruh kurang dapat menjadikan biomass cukup produktif, walaupun perairan itu mempunyai unsur hara yang cukup. Kekeruhan mengurangi intensitas cahaya matahari yang masuk ke dalam badan air. Cahaya yang sampai pada permukaan laut atau danau atau rawa dan jenis perairan lainnya sangat diperlukan untuk proses fotosintesis.

Kecepatan arus berkisar antara 0,1-0,4 m/s baik pasang maupun surut. Kecepatan arus tersebut dipengaruhi oleh pasang surut dan cuaca atau kecepatan angin saat pengambilan sampel. Menurut Hardikusumah (2009) arus dapat dipengaruhi oleh pasang surut serta angin musim. Menurut Nontji (1993) dalam Aprianti et al. (2015) menyatakan bahwa arus merupakan pencerminan langsung dari musim, pola angina yang bertiup, dan akan mempengaruhi lapisan air di bawahnya. Arus dapat mendistribusikan unsur hara yang berasal dari muara sungai menuju perairan yang lebih dalam. Kecepatan arus juga mempengaruhi sebaran atau distribusi dari fitoplankton, karena fitoplankton bergerak melayang-layang mengikuti arus.

Kandungan oksigen terlarut (DO) di lokasi penelitian baik psang maupun surut berkisar antara 0,3-3,4 mg/L. Kandungan oksigen terlarut (DO) minimum adalah $2 \mathrm{mg} / \mathrm{L}$ dalam keadaan normal dan tidak tercemar oleh senyawa beracun (toksik). Kandungan oksigen terlarut minimum ini sudah cukup mendukung kehidupan organisme (Salmin, 2005). Rendahnya kadar oksigen terlarut (DO) di lokasi penelitian umumnya disebabkan adanya limbah dari aktivitas masyarakat.

Nilai derajat keasaman $(\mathrm{pH})$ berkisar antara 6-7. Nilai tersebut masih tergolong baik. Menurut Odum dalam Isnaini et al. (2012) perairan dengan $\mathrm{pH}$ antara 6-9 merupakan perairan dengan kesuburan tinggi dan tergolong produktif karena memilik kisaran $\mathrm{pH}$ yang dapat mendorong proses pembongkaran bahan organic yang ada dalam perairan menjadi mineral-mineral yang dapat diasimilasikan oleh fitoplankton.

Nilai salinitas pada lokasi penelitian berkisar antara 15-30 ppt saat pasang dan 9-27 ppt saat surut. Menurut pendapat Milero dan Sohn (1992) dalam Efrizal (2007) yang menyatakan bahwa fitoplankton dapat berkembang dengan baik pada salinitas 15-32 ppt. Salinitas sangat berpengaruh terhadap sebaran fitoplankton. Fitoplankton yang kurang mampu beradaptasi dengan tingkat salinitas tinggi persebarannya tidak merata di semua titik setiap stasiunnya. Hal ini diperkuat oleh Sulardiono et al. (2015) bahwa setiap spesies fitoplankton mempunyai daya respon terhadap salinitas yang berbeda-beda. Oleh karena itu, sebaran komunitas fitoplankton sangat ditentukan oleh sebaran nilai salinitas di perairan.

\section{KESIMPULAN}

Berdasarkan hasil penelitian yang telah dilakukan, dapat disimpulkan bahwa :

1. Konsentrasi nitrat saat pasang dan surut berada dalam kisaran $2,52-4.34 \mathrm{mg} / 1$ dan 2,85-3,45 mg/l termasuk dalam perairan mesotrofik. Sedangkan konsentrasi fosfat saat pasang dan surut berkisar antara $0,22-4,14 \mathrm{mg} / \mathrm{l}$ dan 0,17 $0,86 \mathrm{mg} / \mathrm{l}$ termasuk dalam perairan eutrofik.

2. Kelimpahan fitoplankton berkisar antara $1168-9045$ ind/liter. Indeks keanekaragaman pasang rata-rata berkisar antara 1,22-1,83 saat surut 1,44-1,81. Indeks keseragaman pasang rata-rata berkisar antara 0,53-0,93 sedangkan saat surut $0,81-0,93$. Indeks dominasi pasang rata-rata $0,17-0,46$ saat surut $0,18-0,3$.

3. Hasil uji regresi linier berganda menunjukkan pada saat pasang ada hubungan erat antara konsentrasi nitrat dan fosfat dengan kelimpahan fitoplankton sedangkan pada saat surut hubungan konsentrasi nitrat dan fosfat dengan kelimpahan fitoplankton lemah.

\section{UCAPAN TERIMAKASIH}

Ucapan terimakasih ditujukan kepada Ir. Siti Rudiyanti, M.Si yang telah memberikan saran dan kritik yang sangat bermanfaat bagi penulis. Kepada semua pihak yang telah membantu sehingga penulis dapat menyelesaikan artikel ini. 


\section{DAFTAR PUSTAKA}

Basmi, J. 1999. Planktonologi Bioekologi Plankton Algae. Fakultas Perikanan dan Ilmu Kelautan. IPB. Bogor. 110.

Effendi, H. 2003. Telaah Kualitas Air Bagi Pengelolaan Sumberdaya Air dan Lingkungan Perairan. Kanisius, Yogyakarta, $258 \mathrm{hlm}$.

Efrizal.T. 2007. Hubungan Beberapa Parameter Kualitas Air Dengan Kelimpahan Fitoplankton di Perairan Pulau Penyengat Kota Tanjung Pinang Provinsi Kepulauan Riau. Universitas Raja Ali Haji Tanjungpinang.

Faza, M.F. 2012. Struktur Komunitas Plankton di Sungai Pesanggrahan dari Bagian Hulu Bogor Jawa Barat hingga Bagian Hilir (Kembangan DKI Jakarta). [SKRIPSI]. Depok: FMIPA Universitas Indonesia.

Handoko, M.Yusuf dan S.Y. Wulandari. 2013. Sebaran Nitrat dan Fosfat Dalam Kaitannya dengan Kelimpahan Fitoplankton di Kepulauan Karimunjawa. Buletin Oseanografi Marina Jurusan Ilmu Kelautan Fakultas Perikanan dan Ilmu Kelautan Universitas Diponegoro. 2 (1) : 48-53.

Hidayat, R, L. Viruly dan D. Azizah. 2013. Kajian Kandungan Klorofil-a Pada Fitoplankton Terhadap Parameter Kualitas Air di Teluk Tanjung Pinang Kepulauan Riau. Fakultas Ilmu Kelautan dan Perikanan, Universitas Maritim Raja Ali Haji. Riau

Isnaini. 2012. Struktur Komunitas Fitoplankton di Perairan Muara Sungai Banyuasin Kabupaten Banyuasin Sumatera Selatan. Universits Sriwijaya. Maspari Jurnal 4 (1) : 58-68.

Jannah,R. dan Z.A. Muchlisin. 2012. Komunitas Fitoplankton di Daerah Estuari Krueng Aceh, Kota Banda Aceh. ISSN: 2089-7790 Jurnal Depik. 1(3) : 189-195.

Kamilah,F., F. Rachmadiarti dan N.K. Indah. 2014. Keanekaragaman Plankton yang Toleran terhadap Kondisi Perairan Tercemar di Sumber Air Belerang, Sumber Beceng Sumenep, Madura. Jurnal Lentera Bio 3 (3) : 226-231.

Mackentum, K.M. 1969. The Practice of Water Pollution Biology. United States Department of Interior, Federal Water Pollution Control Administration, Divisionof Technical Support.

Odum, E.P. 1993. Dasar-Dasar Eekologi. Yogyakarta: Gajah Mada University Press.

Purwanti, S., R. Hariyati dan E. Wiryani. 2011. Komunitas Plankton pada saat Pasang dan Surut di Perairan Muara Sungai Demaan Kabupaten Jepara. Jurusan Biologi, Fakultas Sains dan Matematika, Universitas Diponegoro. Semarang.

Qiptiyah, M., Halidah dan M. A. Rakhman. 2008. Struktur Komunitas Plankton Di Perairan Mangrove Dan Perairan Terbuka Di Kabupaten Sinjai, Sulawesi Selatan. Jurnal Penelitian Hutan dan Konservasi Alam. 5 (2): 137-143.

Sachlan, M. 1982. Planktonologi. Fakultas Peternakan dan Perikanan Undip. Semarang

Salmin. 2005. Oksigen Terlarut (DO) dan Kebutuhan Oksigen Biologi (BOD) Sebagai Salah Satu Indikator Untuk Menentukan Kualitas Perairan. Jurnal Oseana. 30 (3) : 21-26 